ACTA AGROBOTANICA

Vol. 61 (2): 75-83

2008

\title{
PHOTOSYNTHETIC ACTIVITY OF SOME DOMESTIC AND FOREIGN CULTIVARS OF LOLIUM PERENNE L. UNDER CONDITIONS OF SODIUM CHLORIDE SALINITY
}

\author{
Edward Borowski \\ Department of Plant Physiology, \\ University of Life Sciences in Lublin, Akademicka 15, 20-950 Lublin, Poland \\ e-mail: fizjologia.roslin@up.lublin.pl
}

Rezeived: 30.07 .2008

$\mathrm{S} \mathrm{u} \mathrm{m} \mathrm{m} \mathrm{a} \mathrm{r} \mathrm{y}$

In pot experiments carried out in 2005 and 2006, tolerance to sodium chloride salinity of 4 cultivars of perennial ryegrass (Lolium perenne) ('Nira', 'Stadion', 'Ronija', 'Darius') was studied. Three concentrations of $\mathrm{NaCl}$ in medium (earth + sand): $0.0 \mathrm{mM}$ (control); $50 \mathrm{mM} ; 100 \mathrm{mM}$, were used in the investigations. In three successive crops of grass, fresh weight yield of leaves, stomatal conductance, photosynthesis intensity, content of chlorophyll and PS II maximum quantum yield $\left(\mathrm{F}_{\mathrm{v}} / \mathrm{F}_{\mathrm{m}}\right)$ were determined. The obtained results showed that perennial ryegrass is a species tolerant to $\mathrm{NaCl}$ salinity. Among the studied cultivars, cv. 'Ronija' showed the highest tolerance, whereas cv. 'Nira' showed the lowest. The growth of perennial ryegrass plants under salinity conditions was limited by low stomatal conductance of leaves and photosynthesis, but not by the photosynthetic activity of chlorophyll and its contents.

Key words: Lolium perenne, cultivars, $\mathrm{NaCl}$ salinity, photosynthetic activity

\section{INTRODUCTION}

In Poland a mixture of sand and sodium chloride has been used for ice and snow control on roads for several dozen years with good effect. As a result of that, vegetation used for the establishment of lawns within cities and of green belts along transport routes outside cities should exhibit increased resistance to $\mathrm{NaCl}$ salinity. S t a w i c k a et al. (2006) report that salinity on urban lawns in Warsaw ranged between 0.3 and $1.2 \mathrm{dS} \mathrm{x} \mathrm{m}^{-1}$, and among monocotyledonous species, red fescue (Festuca rubra), perennial ryegrass (Lolium perenne) and smooth-meadow grass (Poa pratensis) proved to be most useful for the establishment of lawns. The high share of these grass species in the floristic composition of Warsaw's lawns is also confirmed by Wy s o c k i (1994).
Salinity of the environment primarily reduces soil water potential and, as a consequence, it induces water stress in plants associated with impeded $\mathrm{H}_{2} \mathrm{O}$ uptake called the "physiological drought". Plants respond to salinity with the inhibition of growth rate and biomass production (S e e mann and Critchley, 1985; Horst and Dunning, 1989; A 1 desuquy and Ibrahim, 2001; D as et al. 2002; R a s muson and Anderson, 2002; Borowski, 2003; Khaleghi and Ramin, 2005; Akram et al. 2007), which results from the activation of adaptation processes. Adaptation processes which enable plants to function under stress conditions consist primarily in increased uptake of $\mathrm{Na}^{+}$and $\mathrm{Cl}^{-1}$ hydrophilic ions occurring in excess, as well as in biochemical and physiological changes associated in particular with chlorophyll synthesis ( $\mathrm{S}$ a i ra m and S rivastava, 2002; B orowski, 2003; A kram et al. 2007), the pattern of primary photosynthetic reactions in chloroplasts (M ishra et al. 1991; Havaux, 1992; Jime ne z et al. 1997; L $i$ et al. 1999; Yongeng et al. 2004) and gas exchange in leaves ( $\mathrm{S}$ e e $\mathrm{m}$ a $\mathrm{n} n$ and Critchley, 1985; Li et al. 1999; D a s et al. 2002; Rasmuson and Anderson, 2002; Tattini et al. 2002; B or o w s k i, 2003).

Grass plant species recommended for lawn establishment differ in their resistance to salinity. According to Yong q in et al. (2003), tolerance of grasses to salinity during the germination period was as follows: perennial ryegrass $>$ tall fescue (Festuca arundinaceum) $>$ creeping bent (Agrostis stolonifera) $>$ smooth-meadow grass. But it was slightly different at later growth stages ( $\mathrm{H} \mathrm{u} \mathrm{j} \mathrm{u} \mathrm{n} \mathrm{et} \mathrm{al.} \mathrm{2001):} \mathrm{perennial}$ ryegrass $>$ red fescue $>$ tall fescue $>$ smooth-meadow grass. High tolerance of perennial ryegrass to salinity was also confirmed by Pawluskiewicz (2000) in studies carried out under Polish conditions. At the 
same time, all these three authors found distinct differences in resistance to $\mathrm{NaCl}$ in the studied grass species. Because plants which tolerate a particular type of stress are generally also resistant to other stresses, the present paper compares the response to salinity of two ryegrass cultivars ('Nira' and 'Stadion'), quite commonly used in domestic mixtures, to a Swedish cultivar 'Ronija' used in a more severe climate and a Dutch cultivar 'Darius' used in a milder climate. The sensitivity of these cultivars to salinity was evaluated based on the photosynthetic activity of plants and biomass production.

\section{MATERIALS AND METHODS}

The experiments were carried out in a plant house in the period April - October in the years 2005 and 2006. Seeds of two Polish cultivars of Lolium perenne ('Nira', 'Stadion'), the Swedish cultivar 'Ronija' and the Duch cultivar 'Darius' were sown in the amount of 30 seeds of each ( 3 seeds in 10 points) into $2.0 \mathrm{dm}^{3}$ pots filled with a mixture of garden mould and river sand in a 3:1 volume ratio. The used earth contains less than $85 \%$ of organic substance, its $\mathrm{pH}$ in $\mathrm{H}_{2} \mathrm{O}$ is $5.4-6.0$, and it is manufactured by the company Hollas from Pasłęk, Poland. Each of the four cultivars was grown in 15 pots. After emergence, unnecessary seedlings were removed from the pots, leaving 10 plants of each cultivar for further growing, as well as the plants were supplemented with a half-concentration of Hoagland's medium. The second dose at the same amount was applied a week later. At the same time, for each cultivar 3 experiment series were set up which differed in the degree of sodium chloride salinity of the substrate, i.e. 1) control $-0.0 \mathrm{NaCl}$ 2) $50 \mathrm{mM}$ $\times \mathrm{dm}^{-3} \mathrm{NaCl}$ 3) $100 \mathrm{mM} \times \mathrm{dm}^{-3} \mathrm{NaCl}$. Sodium chloride was applied 8 times at 3-day intervals, depending on the level of substrate salinity at a dose of, respectively, 12.5 and $25 \mathrm{mM}$ per pot in the form of aqueous solution. In the years 2005 and 2006 the last dose of $\mathrm{NaCl}$ was given, respectively, on 6 and 9 June, and the first grass crop was harvested on June 13 and 16, respectively. The next four crops of grass were harvested at 30-day intervals. Throughout the growth period, the plants were watered with distilled water up to $70 \%$ of substrate water-holding capacity.

The present paper presents fresh weight yield of leaves of the studied Lolium perenne cultivars from the first, second and third crop (Tab. 1) as well as results of measurements of photosynthesis intensity (Tab. 2), stomatal conductance (Tab. 3) and chlorophyll content (Tab. 4). Data on maximum quantum yield of PS II in leaves are not included due to the absence of a significant effect of the experiment factors on the value of $\mathrm{F}_{\mathrm{v}} / \mathrm{F}_{\mathrm{m}}$. Since a similar reaction of the investigated culti- vars to the applied salinity levels was observed in both years of study, data presented in the tables are means for the years 2005 and 2006. Photosynthesis intensity and stomatal conductance of leaves were determined using a portable infra-red gas analyser LCA-4 attached to a narrow leaf chamber. Measurements were each time made in the middle parts of leaf blades, 1-3 days before the harvest at noon hours, at an irradiance of $1500-1700 \mu \mathrm{mol} \mathrm{m}{ }^{-2} \times \mathrm{s}^{-1}$. The content of chlorophyll " $\mathrm{a}+\mathrm{b}$ " was determined using the spectrophotometric method described by A rn on (1949). Maximum quantum yield of photosystem II (PS II) was determined in the same parts of leaves as for photosynthesis using the Handy PEA fluorimeter (manufactured by Hensatech Instruments Ltd) after the investigated portions of leaf blades had been earlier obscured for 15 minutes using special clips. Measurement and analysis results were statistically verified using analysis of variance, whereas the significance of differences was determined by Tukey's test at $\mathrm{p}=0.05$.

\section{RESULTS AND DISCUSSION}

The results collected in Tab. 1 show that increased substrate salinity resulted in a significant decrease in fresh weight yield of leaves in all three crops of grass. At the salinity of $50 \mathrm{mM}$, the mean decrease in yield for the four investigated cultivars was $19.1 \%$, compared to the control, and at the salinity of $100 \mathrm{mM}$ as much as $51.2 \%$. Such response of Lolium perenne to the applied stress is confirmed by numerous authors conducting research both on grasses (Horst and Dunning, 1989; Rasmuson and Anderson, 2002; Khaleghi and Ramin, 2005; A kram et al. 2007) and on other cultivated plant species (S e e mann and Critchley, 1985; Aldesuquy and Ibrahim, 2001; Das et al. 2002; B orowski, 2003). However, the mean decrease of biomass yield for 3 grass crops harvested, compared to the control, was similar for the investigated cultivars at the salinity of $50 \mathrm{mM}$ and distinctly different at the salinity of $100 \mathrm{mM}$, and it was $59.1 \%$ for cv. 'Nira', 'Stadion' $54.8 \%$, 'Ronija' 37.6\%, 'Darius' $47.5 \%$. Significant differences in yielding of cv. 'Ronija', compared to the other cultivars, are also confirmed by statistical analysis. Other authors conducting research on cultivars other than those used in the experiment (Yong q in et al. 2003; Huju n et al. 2001; P aw luski ew i c z, 2000) also confirm clear differences in tolerance to salinity of various ryegrass cultivars.

Irrespective of the level of substrate salinity, fresh weigh yields of grass significantly increased in successive crops. It is undoubtedly associated with the process of adaptation of plants to stress conditions. Because salinity stress reduced substrate water potential, 


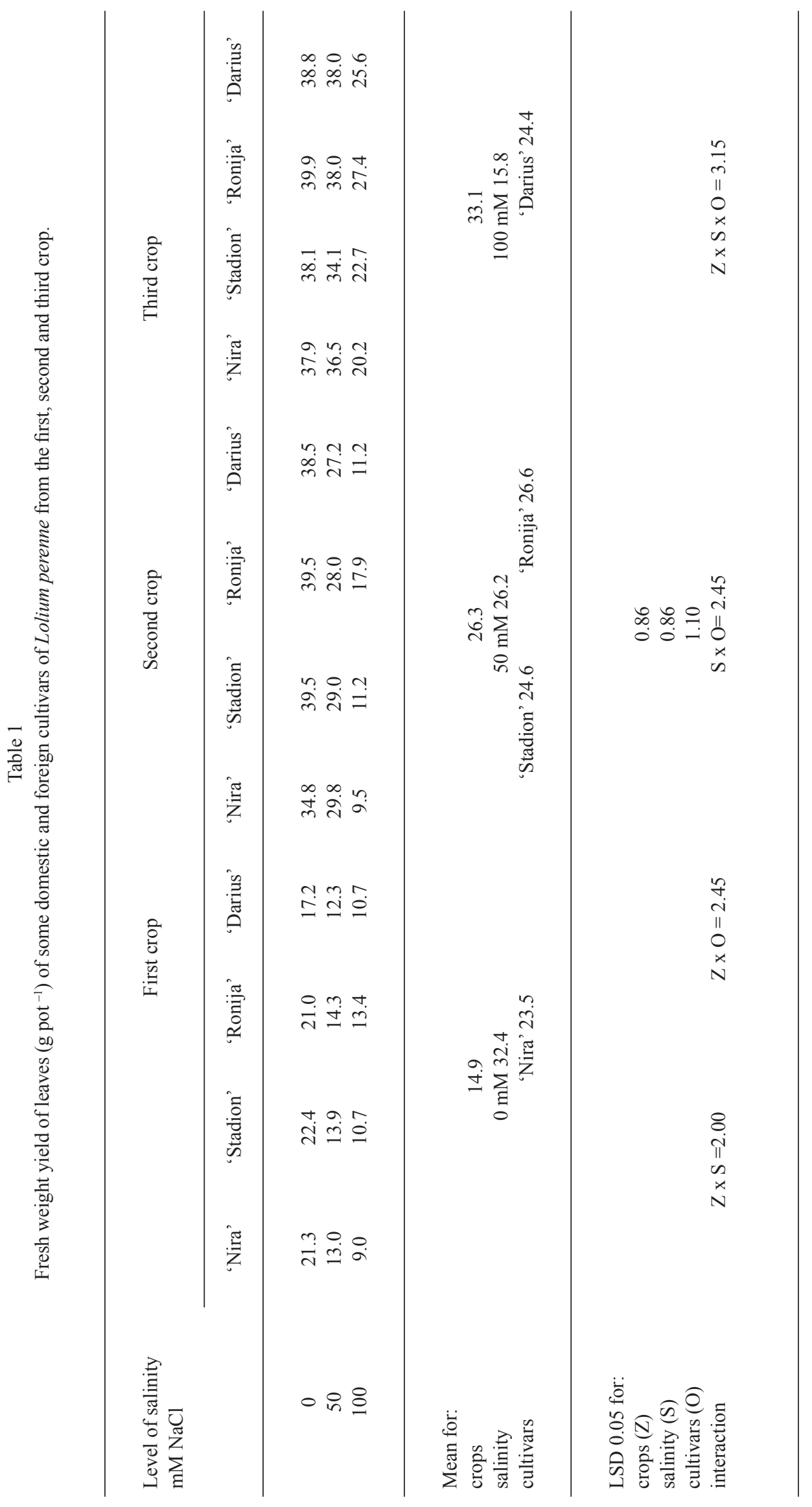




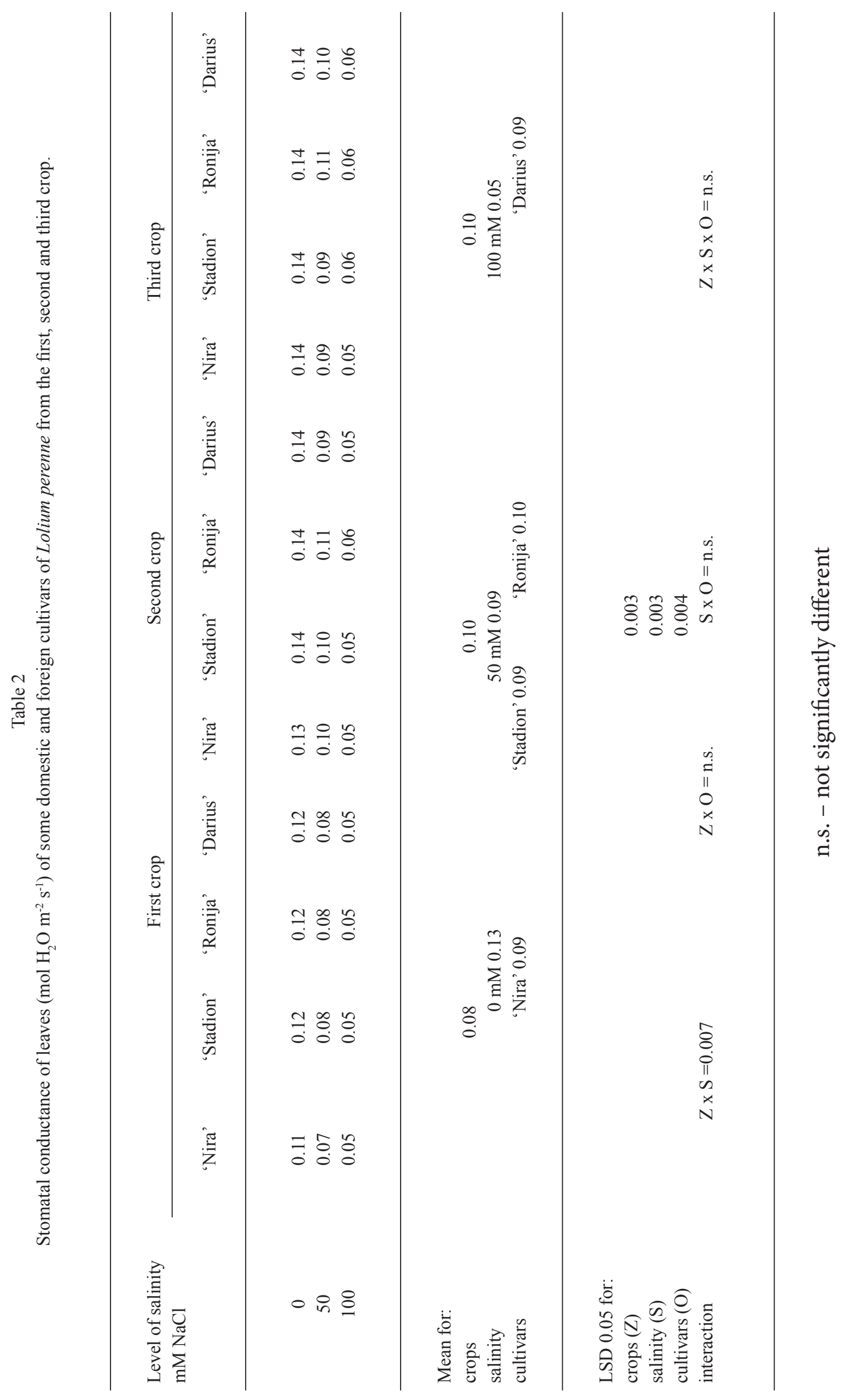




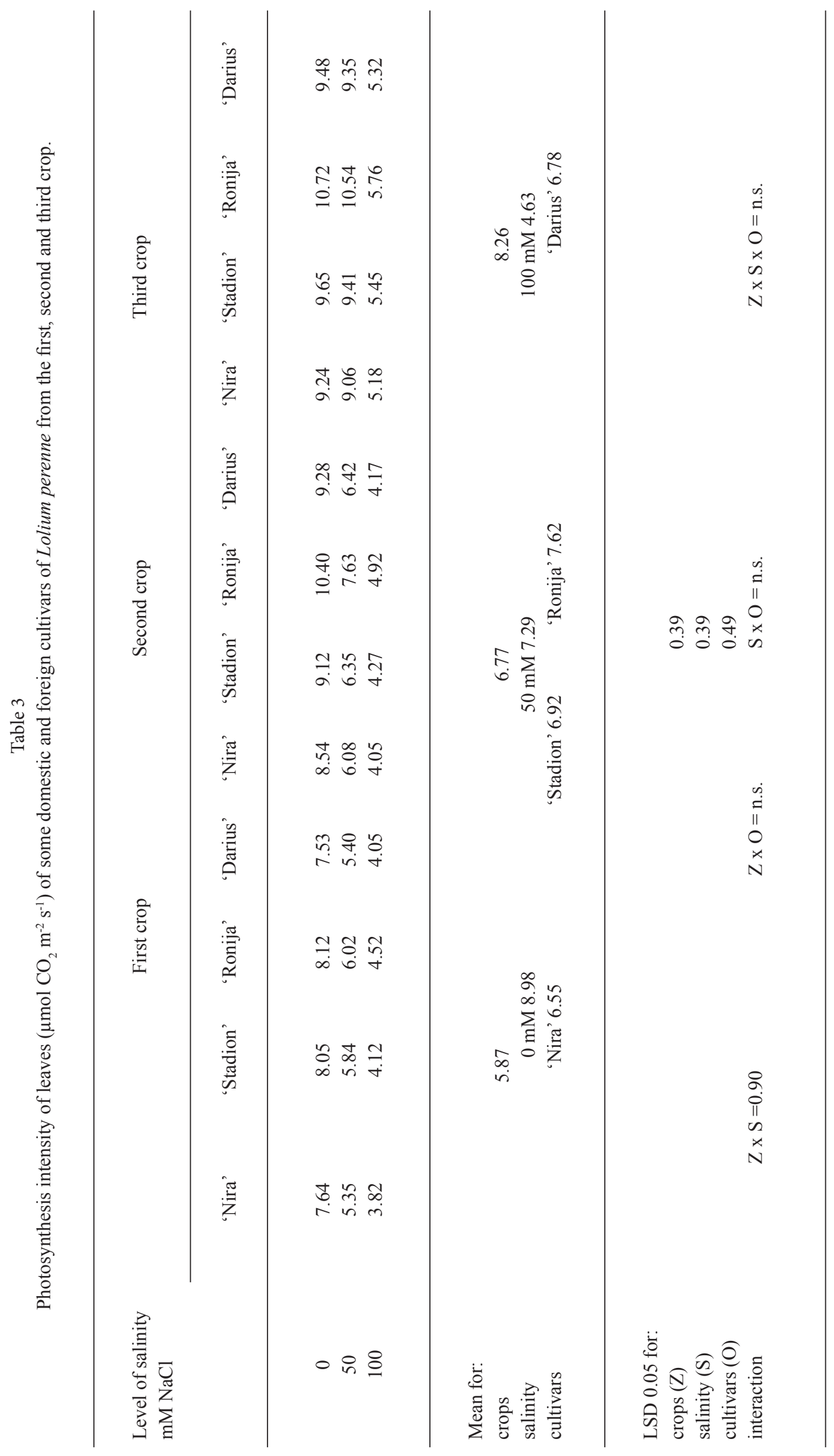




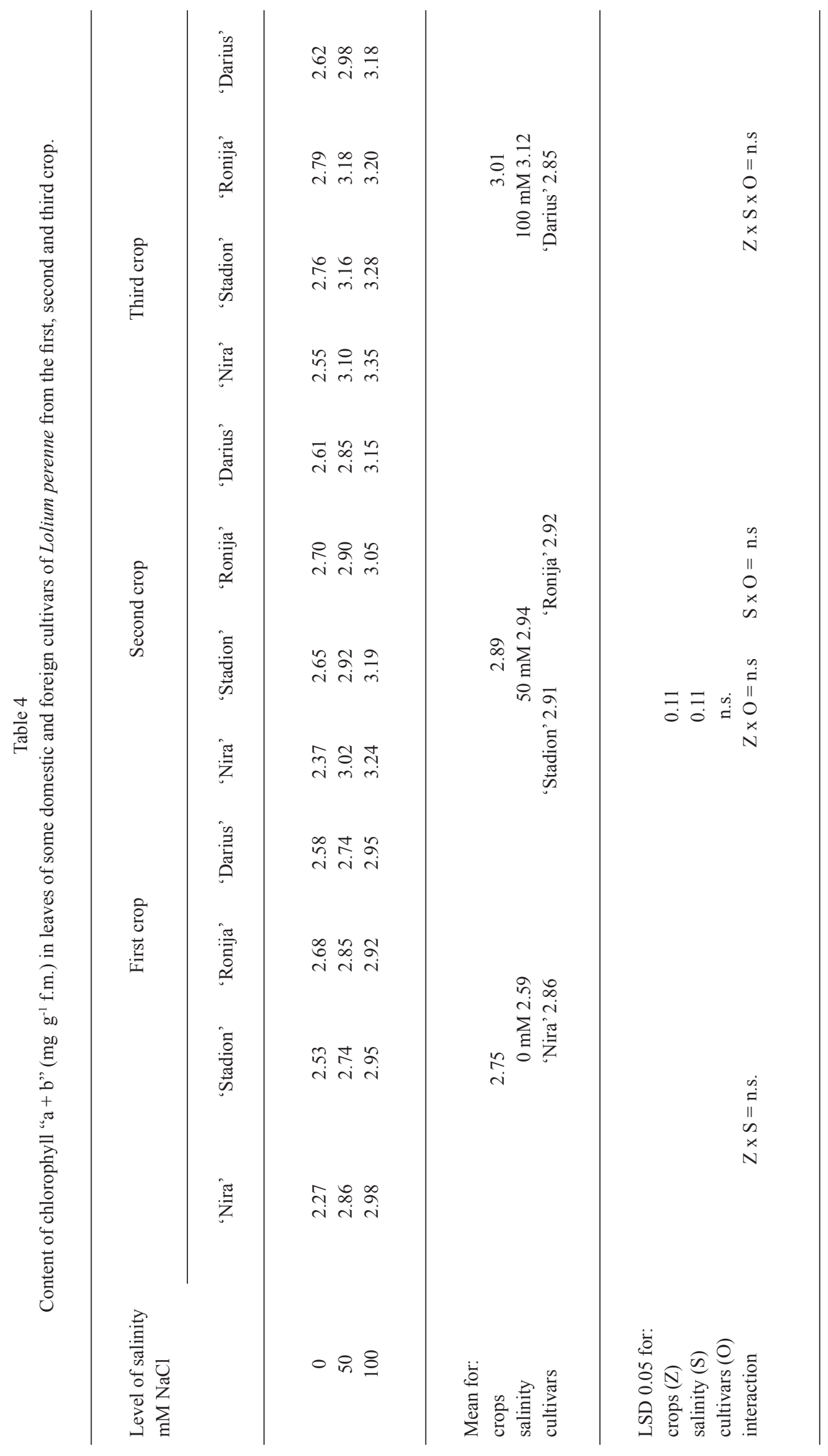


which was associated with the hindered uptake of water by roots, the plants, on the one hand, increased the osmotic potential of cell sap by increased accumulation of hydrophilic ions $\left(\mathrm{Na}^{+}, \mathrm{Cl}^{-}\right)(\mathrm{B}$ or ow sk i, 2007), and on the other hand, they limited transpiration (unpublished data) through reduced stomatal conductance of leaves. Data contained in Tab. 2 show that the mean stomatal conductance of the control plants $(0 \mathrm{mM} \mathrm{NaCl})$ was $0.13 \mathrm{~mol} \mathrm{~m}^{-2} \times \mathrm{s}^{-1}$, whereas at the salinity of $50 \mathrm{mM} \mathrm{NaCl}$ it decreased to 0.09 , and at the salinity of $100 \mathrm{mM} \mathrm{NaCl}$ down to $0.05 \mathrm{~mol} \mathrm{~m}^{-2} \times \mathrm{s}^{-1}$. Hence, in effect, the mean intensity of transpiration of the control plants was $1.95 \mathrm{mmol} \mathrm{H}_{2} \mathrm{O} \mathrm{m}^{-2} \mathrm{~s}^{-1}$, and at the salinity of 50 and $100 \mathrm{mM} \mathrm{NaCl}$ it decreased, respectively, to 1.28 and $0.69 \mathrm{mmol} \mathrm{H}_{2} \mathrm{O} \mathrm{m}^{-2} \mathrm{~s}^{-1}$ (unpublished data). A decrease in stomatal conductance of leaves with respect to water vapour under salinity stress conditions was observed in grasses by $\mathrm{R}$ a s mus on and A nderson (2002) and A kram et al. (2007), as well as in other cultivated plants by $\mathrm{S} \mathrm{e} \mathrm{e} \mathrm{-}$ mann and Critchley (1985), Salas et al. (2001) and Borowski (2003), whereas Tattini et al. (2002) even found changes in stomata distribution. The obtained results demonstrated that mean stomatal conductance of ryegrass leaves from the first crop was significantly lower $\left(0.08 \mathrm{~mol} \mathrm{~m}^{-2} \times \mathrm{s}^{-1}\right)$ than that from the next two crops $\left(0.10 \mathrm{~mol} \mathrm{~m}^{-2} \times \mathrm{s}^{-1}\right)$, which should be recognised as the effect of adaptation of grass to growth under stress conditions, as well as that mean stomatal conductance of leaves of cv. "Ronija" was significantly higher than in the other studied cultivars (Tab. 2).

The degree of pore opening in Lolium perenne leaves had an effect not only on the rate of diffusion of water vapour particles, but also on the rate of diffusion of $\mathrm{CO}_{2}$ into the leaf interior, which was one of the conditions for efficient photosynthesis. $\mathrm{CO}_{2}$ assimilation was the fastest in the control plants $\left(8.98 \mu \mathrm{mol} \mathrm{CO}_{2}\right.$ $\left.\mathrm{m}^{-2} \times \mathrm{s}^{-1}\right)$, at the salinity of $50 \mathrm{mM} \mathrm{NaCl}$ there was an almost 19\% decrease in intensity of this process, and at the salinity of $100 \mathrm{mM}$ the decrease was over $50 \%$. Many other authors conducting research on both grasses (R a mus on and Anderson, 2002; A kram et al. 2007) and dicotyledonous plants (S e e $\mathrm{m}$ a $\mathrm{n} n$ and Critchley, 1985; Li et al. 1999; D a s et al. 2002; B o r o w s k i, 2003) found a clear decrease in the photosynthesis process under conditions of plant salinity. Irrespective of the degree of salinity and dates of harvesting, $\mathrm{CO}_{2}$ was fixed most efficiently in leaves of cv. 'Ronija' ryegrass plants, significantly weaker in cv. 'Darius' and 'Stadion', and the weakest in cv. 'Nira' (Tab. 3).

The $\mathrm{CO}_{2}$ fixation rate in plants is affected not only by the degree of stomata opening, but also by the chlorophyll content in leaves and the rate of primary photosynthetic reactions at the photosystem level. The results collected in Tab. 4 show that the growing level of substrate salinity increased the mean content of chlorophyll, for if the plants in non-saline substrate contained, on the average, $2.59 \mathrm{mg}$ in 1 gram of leaf fresh weight, in the plants growing at the salinity of $50 \mathrm{mM}$ its content increased to $2.94 \mathrm{mg}$, and at the salinity of $100 \mathrm{mM}$ up to $3.12 \mathrm{mg}$. The investigated ryegrass cultivars did not differ significantly in this trait. But other authors' studies on grass (S a i r a m and S riva s t a $\mathrm{va}, 2002$; A kram et al. 2007) as well as on bean (S e emann and Critchley, 1985) and soybean (B o r ow ski, 2003) do not confirm this correlation. It is difficult to explain; it can only be presumed that the applied salinity levels were too low to induce the inhibition of chlorophyll synthesis. Studies of $\mathrm{H} \mathrm{u} \mathrm{j} \mathrm{u} \mathrm{n}$ et al. (2001), P a w l u s k i e w i c z (2000), Yo n g q in et al. (2003), B o r o w s k i (2007) and also the results of the present study demonstrate that Lolium perenne plants are very tolerant to $\mathrm{NaCl}$ salinity.

Sodium chloride salinity of ryegrass plants did not also have any effect on primary photosynthetic reactions taking place at the chloroplast level. The measurement of maximum quantum yield of PS II, being the ratio of variable chlorophyll fluorescence to maximal chlorophyll fluorescence $\left(\mathrm{F}_{\mathrm{v}} / \mathrm{F}_{\mathrm{m}}\right)$, shows that none of the factors applied in the conducted experiment exhibited a significant effect on the value of the trait in question $\left(\mathrm{F}_{\mathrm{v}} / \mathrm{F}_{\mathrm{m}}\right.$ ranged between 0.802 and 0.824$)$. Other authors' studies conducted on different plant species also confirm the absence of a significant effect of salinity stress on the $\mathrm{F}_{\mathrm{v}} / \mathrm{F}_{\mathrm{m}}$ ratio value $(\mathrm{M}$ is h ra et al. 1991; Havaux, 1992; J i menez et al. 1997; Li et al. 1999). In their studies conducted on Phillyrea latifolia, Tat tin i et al. (2002) also found that salinity-induced water stress in leaves of this plant did not produce irreversible damage in the photosynthetic apparatus. Therefore, the results demonstrated in this paper show that the negative effect of sodium chloride salinity stress on the growth of perennial ryegrass is primarily associated with a reduction in stomatal conductance of leaves, which affects adversely the photosynthesis and, as a consequence, the biomass increase in plants.

\section{CONCLUSIONS}

1. Perennial ryegrass (Lolium perenne) is a species tolerant to sodium chloride salinity; it is manifested by low noxiousness of average concentrations of $\mathrm{NaCl}$ in the substrate $(50 \mathrm{mM})$, as well as by a high degree of adaptation to stress conditions during growing (successive grass corps).

2. The studied ryegrass cultivars showed different tolerance to salinity stress - the most tolerant was cv. 'Ronija', medium tolerant cv. 'Darius' and 'Stadion', and cv. 'Nira' proved to be the least tolerant. 
3. The growth of perennial ryegrass plants under salinity conditions is limited by a decrease in stomatal conductance of leaves and photosynthesis, and not by the photosynthetic activity of chlorophyll $\left(\mathrm{F}_{\mathrm{v}} / \mathrm{F}_{\mathrm{m}}\right)$ and its content in leaves.

\section{REFERENCES}

Akram N. A., Muhammad - Shahbaz, Muhammad Ashraf, 2007. Relationship of photosynthetic capacity and proline accumulation with the growth of differently adapted populations of two potential grasses (Cynadon dactylon L. Pers. and Cenchrus ciliaris) to drought stress. Pakistan J. Bot. 39 (3): 777-786.

Aldesuquy H. S., Ibrahim A. H., 2001. Water relations, abscisc acid and yield of wheat plants in relation to the interactive effect of seawater and growth bioregulators. J. Agro. Crop Sci. 187 (2): 97-104.

Arnon D. J., 1949. Cooper enzymes in isolated chloroplasts: Polyphenoloxidase in Beta vulgaris. Plant Physiol. 24: 1-15.

Borowski E., 2003. Wrażliwość krajowych odmian soi na zasolenie chlorkiem sodu. Cz. I. Wpływ zasolenia podłoża na wzrost roślin, wymianę gazową, nodulację korzeni oraz zawartość sodu i chloru w roślinach. / Sensitivity of domestic soybean cultivars to sodium chloride salinity. Part I. The effect of substrate salinity on plant growth, gas exchange, root nodulation as well as sodium and chlorine content in plants. Ann. UMCS, sect. EEE, 7: 93-102.

Borowski E., 2008. Studies on the sensitivity of some species and cultivars of lawn grasses on salinity with sodium chloride during the seed germination and first year of growth. Folia Hort. 20 (1): 81-98.

Das C., Sengupta T., Chattopadhyay S., Setua M., Das N.K., Saratchandra B., 2002. Involvement of kinetin and spermidine in controlling salinity stress in mulberry (Morus alba L. cv S1). Acta Physiol. Plant. 24 (1): 53-57.

Havaux M., 1992. Stress tolerance of photosystem II in vivo. Antagonistic effects of water, heat and photoinhibition stresses. Plant Physiol. 100: 424-432.

Horst G. L., Dunning N. B., 1989. Germination and seedling growth of perennial ryegrass in soluble salts. J. Amer. Soc. Hort. Sci. 114 (2):338-342.

Hujun L., Youzhen G., Jihe W., Mingui H., Zihui Y., 2001. A comparison on salt tolerance of 28 breeds of cold type lawn grass. Acta Pratacult. Sinica, 10 (3): 52-59.

Jimenez M. S., Gonzales-Rodriguez A. M., Morales D., Cid M. C., Socorro A. R., Caballero M., 1997. Evaluation of chlorophyll fluorescence as a tool for salt stress detection in roses. Photosynthetica, 33: 291-301.

Khaleghi E., Ramin A. A., 2005. Study of the effects of salinity on growth and development of lawns (Lolium perenne L., Festuca arundinacea and Cynodon dactylon). J. Sci. Tech. Agri. Nat. Res. 9 (3): 57-68.
Li J. H., Gale J., Novoplansky A., Barak S., Volokita M., 1999. Response of tomato plants to saline water as affected by carbon dioxide supplementation. II. Physiological responses. J. Hort. Sci. Biotech. 74 (2): 238242.

Mishra S. K., Subrahmanyam D., Singhal G. S., 1991. Interrelationship between salt and light stress on primary processes of photosynthesis. J. Plant Physiol. 138: 92-96.

Pawluskiewicz B., 2000. Kiełkowanie i początkowy rozwój traw gazonowych w warunkach zasolenia i alkalizacji podłoża. / Germination and initial development of turfgrasses in conditions of bed salinization and alkalization. Łąkarstwo w Polsce, 3: 119-128.

Rasmuson K. E., Anderson J. E., 2002. Salinity affects development, growth and photosynthesis in cheatgrass. J. Range Manag. 55 (1): 80-87.

Sairam R. K., Srivastava G. C., 2002. Changes in antioxidant activity in subcellular fractions of tolerant and susceptible wheat genotypes in response to long term salt stress. Plant Science, 162 (6): 897-904.

Salas J. A., Sanabria M. E., Pire R., 2001. Modification of stomatal index and density in tomato plants (Lycopersicon esculentum Mill.) submitted to saline treatments. Bioagro, 13: 99-104

Seemann J. R., Critchley C., 1985. Effects of salt stress on the growth, ion content, stomatal behavior and photosynthetic capacity of a salt sensitive species, Phaseolus vulgaris L., Planta, 164: 151-162.

Stawicka J., Wysocki C., Wieczorek J., 2006. The influence of soil salinity on floral variability of street lawns in Warsaw. Ann. Warsaw Agri. Univ. - SGGW Hort. Land. Arch. 27: 73-81.

Tattini M., Montagni G., Traversi M. L., 2002. Gas exchange, water relations and osmotic adjustment in Phillyrea latifolia grown at various salinity concentrations. Tree Physiol. 22 (6): 403-412.

Wysocki C., 1994. Studia nad funkcjonowaniem trawników na obszarach zurbanizowanych (na przykładzie Warszawy). / Study on the function of lawns in urban development area (on the example of Warsaw). Rozprawy naukowe i monografie. Wyd. SGGW: 1-89.

Yongeng L., Linghao L., Gaoming J., Shuli N., Meizhen L., Leiming G., Yu P., Chuangdao J., 2004. Traits of chlorophyll fluorescence in 99 plant species from the sparse - elm grassland in Hunshandak Sandland. Photosynthetica 42 (2): 243-249.

Yongqin D., Xuefang C., Weiping S., Ping W., 2003. A screening of the salt tolerance variety of lawn grass by biotechnology. Acta Agri. Shanghai, 19 (1): 37-40. 


\section{Aktywność fotosyntetyczna niektórych krajowych i zagranicznych odmian życicy trwałej (Lolium perenne L.) w warunkach zasolenia chlorkiem sodu}

Streszczenie

W doświadczeniach wazonowych prowadzonych w 2005 i 2006 roku badano tolerancję na zasolenie chlorkiem sodu 4. odmian życicy trwałej ('Nira', 'Stadion', 'Ronija', 'Darius'). W badaniach zastosowano 3 stężenia $\mathrm{NaCl}$ w podłożu (ziemia + piasek): 0,0 $\mathrm{mM}$ (kontrola); $50 \mathrm{mM} ; 100 \mathrm{mM}$. W trzech kolejnych zbiorach trawy określono: plon świeżej masy liści, przewodność szparkową, intensywność fotosyntezy, zawartość chlorofilu, maksymalną wydajność kwantową PS II $\left(\mathrm{F}_{\mathrm{v}} / \mathrm{F}_{\mathrm{m}}\right)$. Uzyskane wyniki wykazały, że życica trwała jest gatunkiem tolerancyjnym na zasolenie $\mathrm{NaCl}$, a w obrębie badanych odmian najwyższą tolerancją charakteryzowała się odm. 'Ronija', a najniższą odm. 'Nira'. Wzrost roślin życicy w warunkach zasolenia ograniczany był niską przewodnością szparkową i fotosyntezą, a nie aktywnością fotosyntetyczną chlorofilu $\left(\mathrm{F}_{\mathrm{v}} / \mathrm{F}_{\mathrm{m}}\right)$ i jego zawartością. 